\title{
Ovarian Yolk Sac Tumor with Granulomatous Reaction Resembling Tuberculosis: A Unique Presentation
}

\author{
Shaista VASENWALA ${ }^{1}$, Noor Afshan SABZPOSH ${ }^{2}$, Hena ANSARI ${ }^{1}$, Nazima HAIDER ${ }^{1}$, Shazia PARVEEN², \\ Murad AHMED'
}

Department of ${ }^{1}$ Pathology and ${ }^{2}$ Obstetrics and Gynaecology, Jawaharlal Nehru Medical College, AMU, ALIGARH, INDIA

\section{ABSTRACT}

Yolk sac tumors (endodermal sinus tumors) are an important subgroup of germ cell tumors of the ovary. They are seen in young females and are highly aggressive, but respond well to treatment. Although different morphological patterns can be seen on light microscopy, granulomatous reaction and giant cells are a very rare occurrence. We report the case of a young female with ovarian yolk-sac tumor in which a widespread granulomatous reaction was seen, causing a diagnostic dilemma.

Key Words: Ovary, Germ cell tumor, Granuloma, Giant cells

\section{INTRODUCTION}

Ovarian yolk sac tumors (YST) are malignant germ cell tumors and are most common in children and young females. They are rapidly growing aggressive tumors and are characterized by elevated serum alpha-fetoprotein (AFP) levels and a variety of histologic patterns. However, the presence of giant cells and granulomatous reaction has not been described in YST except for a rare association with syncytiotrophoblastic giant cells (1). We report a case of yolk sac tumor with extensive granulomatous reaction showing numerous giant cells of Langhans type and tumor giant cells. This pattern of YST has not been documented before to the best of our knowledge.

\section{CASE REPORT}

A 21-year old woman, married for four months, nulligravida, with irregular menstrual cycle and oligomenorrhoea, presented with complaint of pain in abdomen for two months. She was afebrile and mildly anaemic. There was no jaundice and lymphadenopathy. Systemic examination was unremarkable. A lump was palpable in right lower abdomen. It was soft to firm, tender and 16-20 weeks uterine size. Vaginal examination revealed fullness in posterior fornix with a tense mass.

Investigations revealed hemoglobin $=10 \mathrm{gm} \%$, total leucocyte count $=12 \times 10^{9} / \mathrm{l}$, differential cell count $=$ polymorphs $70 \%$, lymphocytes $20 \%$, monocytes $5 \%$, eosinophils $5 \%$, erythrocyte sedimentation rate $=40 \mathrm{~mm}$ at 1 hour. Urine examination was negative for sugar, albumin and

(Turk Patoloji Derg 2016, 32:126-129)

Received : 03.12.2012 Accepted : 25.02.2013 blood. Microscopic examination of urine showed 3-4 pus cells (neutrophils)/high power field and 1-2 red cells/high power field. X-ray chest was normal.

Ultrasound examination of the abdomen showed a mass, arising from right adnexa, $15 \mathrm{cms}$ in diameter, with heterogenous echotexture and central necrosis. Serum AFP level was raised to $800 \mathrm{ng} / \mathrm{ml}$ and serum human chorionic gonadotrophin (HCG) was negative.

Right sided salpingo-oopherectomy with appendicectomy and resection of a part of omentum was performed. The ovarian tumor was a partially capsulated round mass, $15 \times 10 \times 5 \mathrm{~cm}$ in size, with slightly nodular glistening outer surface. Cut surface was solid creamish-white with areas of hemorrhage and necrosis in the center. Appendix was $6 \times 1 \mathrm{~cm}$ in size. Omental tissue, $12 \times 4 \mathrm{~cm}$ showed a $0.5 \mathrm{~cm}$ solid white nodule. Formalin fixed, H\&E stained sections revealed a capsulated tumor with central necrosis and hemorrhage. The viable tissue at periphery showed a mixed pattern of yolk sac tumor (Figure1A-C). Most prominent was the reticular pattern made up of clear cells with malignant hyperchromatic, round nuclei, with irregular borders in some nuclei, finely clumped chromatin and small nucleoli. The other patterns were glandular structures and Schiller- Duval bodies. Numerous giant cells with peripherally arranged and also centrally placed nuclei representing granulomatous reaction were scattered evenly throughout the tumor parenchyma and were associated with all the patterns of YST (Figure 1B-D). The nuclei of giant cells resembled the tumor nuclei. A few epithelioid

Correspondence: Hena ANSARI

Jawaharlal Nehru Medical College, AMU, Department of Pathology,

ALIGARH, INDIA

E-mail: hena.jnmc@gmail.com Phone: +0571272 1191 
cells and a thin rim of mature lymphocytes were seen around some of the giant cells. Caseous necrosis was not seen. Periodic acid-Schiff stain (PAS) positive globules were seen lying free and also inside the cell (Figure 2A). Immunostain for AFP (FLEX polyclonal rabbit anti-human Alpha-1-fetoprotein, code IS500, ready to use, DAKO, Denmark) was only focally positive (Figure $2 \mathrm{~B}-\mathrm{D}$ ). The giant cells showed diffuse and strong positivity positively for CD68 (Clone KP-1, catalog no. PM 033AA, ready to use, Biocare Medical, USA) (Figure 3A-C), supportive of a monocytic - macrophage origin. Nodule in omental tissue showed focus of YST with giant cells. Appendix showed chronic inflammation.

As tuberculosis is prevalent in our country the patient was investigated for co-existent tuberculosis. Mantoux test and serum IgG- IgM antibodies for tuberculosis were negative. All the sections of the tumor were negative for acid fast bacilli (AFB). There was no lymphadenopathy and X-ray chest was normal. A diagnosis of yolk sac tumor with granulomatous giant cell reaction with metastasis in omentum was made.

\section{DISCUSSION}

Varied architectural patterns can be identified on light microscopy in yolk sac tumours (YST). Associated features include Schiller-Duval bodies and hyaline globules. Although syncytiotrophoblastic giant cells have rarely been described in YST (1), other types of giant cells or granulomatous reaction have not been reported in YST to the best of our knowledge. In the case under study, we found a profound granulomatous reaction in the form of
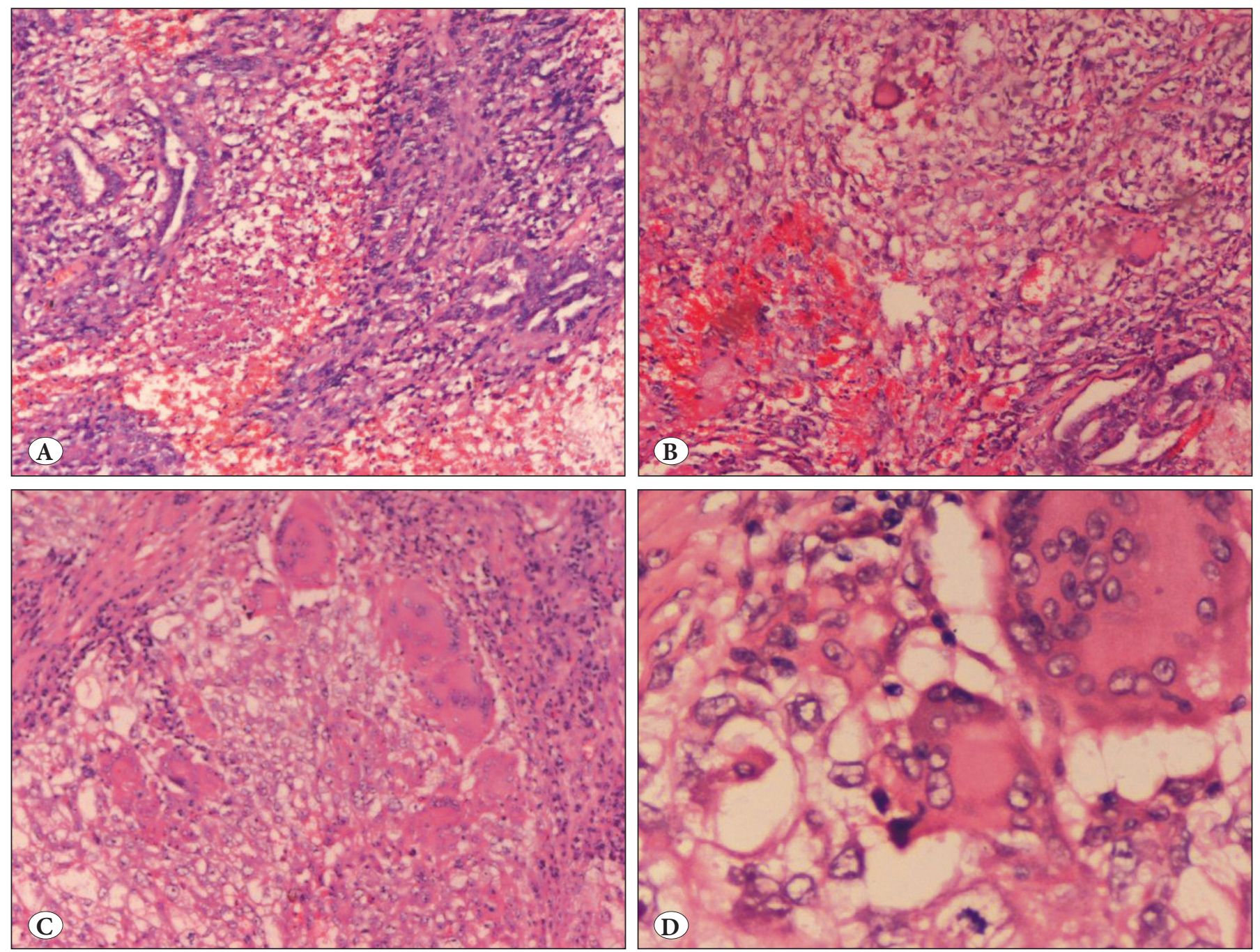

Figure 1: A-C) Sections of YST showing sheets of malignant cells, Schiller-Duval bodies, glands and hyaline globules, and reticular pattern with scattered giant cells (H\&E; x10). D) Langhans' type giant cell with peripherally arranged and also centrally placed nuclei (H\&E; $\mathrm{x} 40)$. 

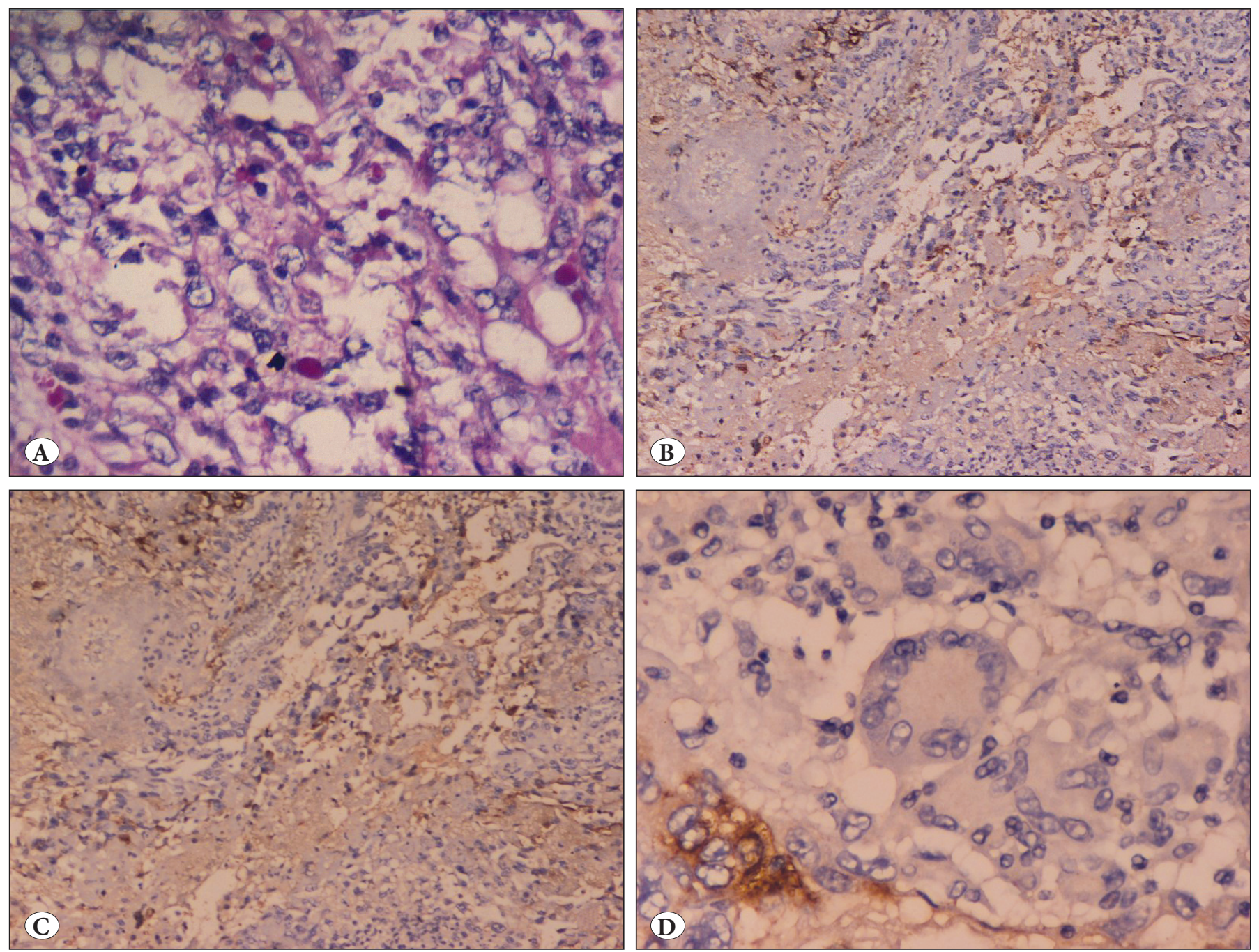

Figure 2: A) Intra and extracytoplasmic PAS positive globules in YST (PAS; x10). B-D) Immunostaining for AFP showing focal positivity.
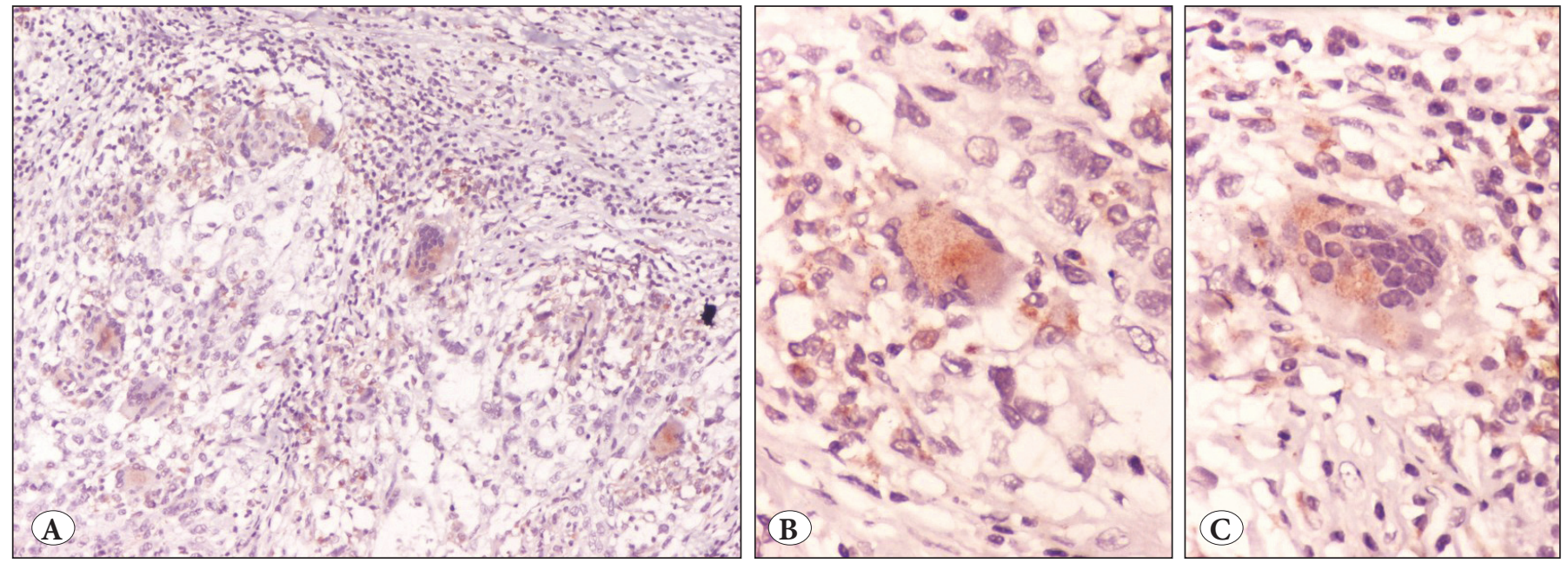

Figure 3: A-C) Immunostain for CD68 showing positivity in cytoplasm of giant cells in tumor areas. 
evenly distributed giant cells with peripheral and centrally placed nuclei, morphologically resembling the nuclei of tumor cells, which is a unique phenomenon. Occasional giant cells were surrounded by a few epithelioid cells and a rim of lymphocytes. No caseous necrosis could be made out in the granulomas. The ischemic necrosis and hemorrhage was confined to the central part of the tumor.

The differential diagnosis of a granulomatous reaction in the ovary includes infections, especially tuberculosis, and non-infective lesions such as sarcoidosis, Crohn's disease, xanthogranulomatous oophritis, foreign body and post-operative granulomas (2-8). Tuberculosis is an important cause of infertility and tubo-ovarian mass in India. Therefore, it was necessary to rule out tuberculosis in this patient. The investigations did not reveal any tubercular focus. Sarcoidosis was excluded as there was no lymphadenopathy and X-ray chest was normal. There were no symptoms related to the gastro-intestinal tract suggestive of Crohn's disease.

Giant cells and granulomatous reactions have been described in other ovarian tumors. Syncytiotrophoblastic giant cells have been found in dysgerminomas and embryonal cell carcinomas $(9,10)$. These are usually positive for HCG. The giant cells in this case were diffusely and strongly positive for the marker CD68 (KP-1). CD68 is a 110-kilodalton glycoprotein which is associated with lysosomes, and is present in the cytoplasm of several cells, including monocytes and macrophages $(11,12)$. The results indicate that the giant cells were of macrophage lineage and reactive in origin.

Giant cells have also been found in the walls of ovarian mucinous and rarely serous cystic neoplasms $(13,14)$. Benign multinucleated giant cells in a background of pleomorphic mononuclear cells have been described in giant cell tumor of ovary, as well as sex cord stromal tumors with malignant giant cells $(15,16)$. In our case, the histologic picture is unique, showing reticular, glandular and SchillerDuval body patterns of YST and granulomatous reaction comprising of reactive multinucleated giant cells which has not been reported before.

\section{REFERENCES}

1. Rabban JT, Zaloudek C. Ovarian Yolk Sac Tumors. Pathology Case Reviews. 2006;11:50-7.

2. McCluggage WG, Allen DC. Ovarian granulomas: A report of 32 cases. J Clin Pathol. 1997;50:324-27.

3. Mondal SK, Dutta TK. A ten year clinicopathological study of female genital tuberculosis and impact on fertility. JNMA J Nepal Med Assoc. 2009;48:52-7.

4. Chow TW, Lim BK, Vallipuram S. The masquerades of female pelvic tuberculosis: Case reports and review of literature on clinical presentations and diagnosis. J Obstet Gynaecol Res. 2002;28:203-10.

5. Fuchs F, Le Tohic A, Raynal P, Guillot E, Chis C, Meckenstock $\mathrm{R}$, Panel P. Ovarian and peritoneal sarcoidosis mimicking an ovarian cancer. Gynecol Obstet Fertil. 2007;35:41-4.

6. Pace EH, Voet RL, Melancon JT. Xanthogranulomatous oophoritis: An inflammatory pseudotumor of the ovary. Int J Gynecol Pathol. 1984;3:398-402.

7. Mostafa SA, Bargeron CB, Flower RW, Rosenshein NB, Parmley $\mathrm{TH}$, Woodruff JD. Foreign body granulomas in normal ovaries. Obstet Gynecol. 1985;66:701-2.

8. al Dawoud A, Yates R, Foulis AK. Postoperative necrotising granulomas in the ovary. J Clin Pathol. 1991;44:524-25.

9. Chakrabarti I, Bera P, Gangopadhyay M, De A. Fine needle aspiration diagnosis of bilateral dysgerminoma with syncytiotrophoblastic giant cells. J Cytol. 2009;26:86-7.

10. Zaloudek CJ, Tavassoli FA, Norris HJ. Dysgerminoma with syncytiotrophoblastic giant cells: A histologically and clinically distinctive subtype of dysgerminoma. Am J Surg Pathol. 1981; 5:361-7.

11. Fukuda M. Lysosomal membrane glycoproteins. Structure, biosynthesis, and intracellular trafficking. J Biol Chem. 1991;266: 21327-30.

12. Pulford KAF, Sipos A, Cordell JL, Stross WP, Mason DY. Distribution of the CD68 macrophage/myeloid associated antigen. Int Immunol. 1990;2:973-80.

13. Yamana K, Kinoshita T, Nakano R, Morimatsu M, Nakashima T. Anaplastic giant cell tumor with mucinous cystadenocarcinoma of the ovary. Acta Pathol Jpn. 1984;34:399-402.

14. Matsuta M, Matsuta M, Kagabu T. Ovarian serous adenocarcinoma with anaplastic areas containing osteoclast-like multinucleated giant cells. International Journal of Clinical Oncology. 2000;5: 280-3.

15. Lorentzen M. Giant cell tumor of the ovary. Virchows Arch A Pathol Anat Histol. 1980;388:113-22.

16. Young RH, Scully RE. Ovarian sex cord-stromal tumors with bizarre nuclei: A clinicopathologic analysis of 17 cases. Int J Gynecol Pathol. 1983;1:325-35. 